\title{
DICHOTOMY IN THE STRUCTURES OF HONORIFICS OF JAPANESE ${ }^{1}$
}

\author{
Misato Tokunaga
}

\section{Introduction}

In discussing the strategies of politeness, Brown and Levinson (1978) claim that treating "the respect for face as norms or values subscribed to by members of a society" (p. 67) is a basic human desire. It seems that all languages have strategies to satisfy this basic human desire. According to Brown \& Levinson, one of the politeness strategies is the use of impersonal constructions, that is, agentless constructions such as passives as in (1). Such impersonal constructions could lead to the assumption that the speaker linguistically indicates his politeness by avoiding expressions which could be interpreted as imposition. Other impersonal constructions involve: dative-agent deletion, as in (2); use of modals with deletion of pronouns to remove traces of person in verbal agreement, as in (3); use of "stativephrasing", i.e. intransitive verbs instead of transitive verbs, as in (4) (Brown \& Levinson 1978: 197-198); and conditionals, as in (5).

(1) It is expected that you follow the instructions

(2) It appears (to me) that you ought to follow the instructions

(3) (nii) ceyyaNum. "(You) should do it"

(Tamil. B \& L, e.g. (341), p.197)

(4) It broke. vs. I broke it. (B \& L, e.g. (347-8), p.198)

(5) It would be helpful if you could follow the instructions

Politeness strategies in Japanese also include use of impersonal constructions such as passives, stative-phrasing and agent-deletion as well as lexical devices. Typically, the inchoative verb naru 'become' or the passive suffix -rare are used for an honorific form of a verb for respect, as seen in (6). Both naru 'become' and -rare

\footnotetext{
${ }^{1}$ I am grateful to the anonymous reviewer for the invaluable comments for the earlier version of this paper. Any remaining shortcomings are my own.
}

Abbreviations:

\begin{tabular}{|c|c|c|c|}
\hline Nom & $=$ nominative & nomlz. & $=$ nominalizer \\
\hline Acc. & $=$ accusative & copl. & $=$ copula \\
\hline Dat. & $=$ dative & Pass. & $=$ passive \\
\hline Top. & $=$ topic marker & Spont. & $=$ spontaneity \\
\hline Agnt. & $=$ agentive & pot. & $=$ potential \\
\hline hon. & $=$ honorifics & Qt. & $=$ quotative \\
\hline $\begin{array}{l}\text { pst. } \\
\text { pres. }\end{array}$ & $\begin{array}{l}=\text { past } \\
=\text { present }\end{array}$ & emph. & $=$ emphasis \\
\hline
\end{tabular}


are normally used in sentences in which agentless constructions are required to impersonalize the expressions: naru 'become' is the verb to describe an event as if it happened "by itself", without explicit identification of the agent, and -rare is the suffix used to form passives which are often referred to as agentless constructions.

"Prof. Tanaka wrote the book"

a. Tanaka-sensei

ga sono

Nom. that

hon 0

book Acc.

o-kaki ni nat-ta n desu

hon-write become-pst. nomlz. copl.

b. Tanaka-sensei ga sono hon o $\begin{aligned} & \text { kak-are-ta n desu } \\ & \text { write-Pass.-pst. }\end{aligned}$

The use of naru 'become' and -rare in the form of "respect" in Japanese honorifics seems to be following the universal strategies of politeness proposed by Brown \& Levinson. However, the strategies of politeness in Japanese seem to be more complicated: there are two types of politeness in Japanese, respect and humility. The respectful form is to indicate the speaker's respect for the referent of the subject of the verb and the humble form is to indicate the speaker's politeness to describe his own action. The focus of this paper is to demonstrate the fact that there is a clear linguistic distinction between the speaker, including "insiders" and others, namely, "outsiders" through the analysis of the structures of honorifics in Japanese ${ }^{2}$.

In Japanese there is a dichotomy in the structure of honorifics. The dichotomy is observed between the verbs and the suffixes used for forms of respect and forms of humility. A form for respect contains either naru 'become' or the passive suffix -rare, while a form for humility contains either suru 'do' or the causative suffix -sase. The respectful form refers to an action of the speaker's superior or a stranger, namely, an "outsider" (an out-group member). The humble form refers to an action of the speaker himself or a person to whom he considers extremely close such as his family member or close friend, namely an "insider" (i.e. an in-group member). Both suru 'do' and causatives explicitly indicate an agent who does the action or makes someone else do the action, while naru 'become' and passives hide such explicit indication. The crucial point is that the humble form is formed with suru 'do' or the causative suffix, which semantically indicate "control" of the subject NP and that the respectful form is formed with naru 'become' or the passive suffix, which has no indication of "control" in the part of the subject NP.

This paper demonstrates how clearly the dichotomy divides the functions of Japanese honorifics, respectful forms and humble forms. My analysis of Japanese pragmatics leads to the concept of "insider" and "outsider". I claim that this concept

\footnotetext{
${ }^{2}$ It is well known that Japan is a society of $u c h i$ "insiders" and soto "outsiders". This dichotomy has been the issue whenever discussing the difference between the societies of Japan and other countries, especially in the west. However, to my knowledge, there has been no analysis presented in linguistics which indicates that the concept of $u c h i$ and soto also underlies in the linguistic structures of the Japanese language.
} 
is engraved in the structure of the Japanese language: A key rule to Japanese pragmatics is a clear distinction between speakers/insiders and others/outsiders.

\section{The Japanese honorifics}

Harada (1976) divides Japanese honorifics into three categories: "Subject honorifics" (SH), "Object honorifics" (OH) and "Performative honorifics" (PH). Harada calls the first two categories "propositional honorifics", thus differentiating them from the third category. Propositional honorifics require human NPs in their propositional contents while performative honorifics do not have this restriction.

"Subject honorifics" applies when the subject NP refers to a person socially superior to the speaker, while "Object honorifics" applies when the subject NP refers to the speaker himself or a person of his in-group, namely, an "insider". Thus, "Subject honorifics" is commonly called the respectful form and "Object honorifics", the humble form. Examples (7) and (8) illustrate these distinctions:

(7) "It rained"

a. (PH) Ame ga furi-mashi-ta (Harada's (5a), p.502) rain Nom. fall-polite-pst.

b. (SH) *Ame ga o-furi ni nat-ta (H's (5b))

c. $(\mathrm{OH})^{*}$ Ame ga o-furi suru

(8)

a. (PH) Yamada-san ga hon o kaki-masu Mr. Nom. book Acc. write-polite

"Mr. Yamada will write/writes a book"

b. (SH) Yamada-san ga hon o o-kaki ni naru/nari-masu

"Mr. Yamada will write/writes a book"

c. $\quad(\mathrm{OH})$ Yamada-san ga hon o o-kaki suru/shi-masu

"Mr. Yamada will write/writes a book (for someone superior to him)"

In (7), neither the respectful form $o-V$ ni naru nor the humble form $o-V$ suru generates a grammatical sentence since the subject NP is non-human NP, while "Performative honorifics" with masu can apply to a non-human NP. On the other hand, (8) shows that all categories apply when the subject NPs are human NPs. The use of naru in (8b) indicates that Mr. Yamada is superior to the speaker and the use of suru in (8c) indicates that he is one of the speaker's in-group, namely, an insider. Masu in (8a) is simply an indication of the speaker's politeness or formality. In the following, Japanese honorific expressions will be described: how they are formed with naru 'become'/-rare for the respectful form and suru 'do'/-sase for the humble form. 


\subsection{Japanese honorific expressions}

A respectful form is used to refer to a person socially superior to the speaker or to an insider. It can be formed by either the use of the inchoative verb naru 'become' or the passive suffix -rare, as seen in (9).

(9)

$\begin{array}{lllll}\text { a. Tanaka-san ga sono sarada o } & \begin{array}{l}\text { o-tsukuri ni } \\ \text { that salad Acc. make }\end{array} & \begin{array}{l}\text { nari-mashita } \\ \text { become }\end{array}\end{array}$
b. Tanaka-san ga sono sarada o tsukur-are-mashita make-Pass.

"Mr. Tanaka made that salad"

Humble expressions which refer to an action of the speaker himself or of the insider can be formed with suru 'do' or the causative suffix -sase, as seen in (10).

$\begin{array}{llll}\text { a. (Watakusi ga) sono sarada o (Tanaka-san } & \text { ni) } & \text { o-tsukuri si-masita } \\ \text { I } & \text { Nom. } & \text { Dat. } & \text { make do }\end{array}$

"(I) made the salad (for Mr. Tanaka)"

b. (Watakusi ga) sono sarada o (Tanaka-san ni) tsukur-ase-te itadak-imashita

Caus.-Ger.

receive-polite

"(I) had (Mr. Tanaka) make/let (me) make the salad"

(Lit.) (I) received the action of (Mr. Tanaka) making (me) make the salad"

c. (Tanaka-san wa) (watakusi ni) sono sarada o tsukur-ase-te kudasai-mashita give

"(Mr. Tanaka) let (me) make the salad"

(Lit.) (Mr. Tanaka) gave (me) an action of (his) making (me) make the salad

The verbs itadaku 'receive' and kudasaru 'give (me)' are the honorific counterparts for morau 'receive' and kureru 'give (me)', respectively. These verbs are used as supporting verbs: itadaku 'receive' indicates that the action denoted by the causative verb phrase is done with the speaker's wishes, and kudasaru 'give' indicates that the action denoted by the causative VP is directed to the speaker and that the speaker is grateful for that. In other words, itadaku 'receive' in (10b) indicates that the speaker asked for permission to make the salad and kudasaru 'give' in (10c) indicates that the speaker is grateful for Mr. Tanaka's permission to let him make the salad. (10c) does not indicate whether the speaker asked for his permission. (10) illustrates that a compound VP of containing a causative and a donatory verb has the pragmatic effect of expressing politeness and because it indicates that the speaker forced Mr. Tanaka to let him make the salad with the causative and expresses his initiative or gratitude by a donatory verb. That is, the semantic 
combination of the two verbs in the VP indicates that the speaker convinced Mr. Tanaka to let him do things for Mr. Tanaka. In this way, it indicates that the agent's action occurred through his initiative and wishes. Therefore, such expressions are considered humble forms which are used when the speaker/insider does something for others.

There are many more ways to express honorifics in Japanese, such as use of lexical devices. However, I shall limit my discussion to the structural dichotomy of Japanese honorifics in this paper. The dichotomy between the use of naru 'become' and suru 'do' and between the passive suffix -rare and the causative suffix -sase is clear in the notion of "control". Naru 'become' and the passive indicate "no control", while suru 'do' and the causative indicate "control" in the part of the referent of the subject. The notion of "control" seems to be crucial to look into in order to understand the structural dichotomy in the Japanese honorifics, since this seems to be quite specific to Japanese.

\subsection{The notion of "control"}

The structural dichotomy of honorifics in Japanese seems to be derived from the conceptual dichotomy of the notion of "control". The question arises as to why the respectful form is expressed by means of the linguistic items which semantically indicate "no control" and the humble form by the items which indicate "control". However, before attempting to answer the question, let us examine the notion of control proposed by Comrie (1981) and that in the Japanese sentences with the suffixes -rare/-sase and the verbs naru/suru.

Comrie (1981) discusses the totality of semantic roles, such as agent, force, instrument, experiencer, and patient in a universal inventory. He claims that these semantic roles are not a set of discrete semantic relations, but rather a continuum along which the labels represent different points. He characterizes the continuum as a continuum of control. There is a degree of control such as full control, potential control, and no control, as exemplified in (11).

a. Full control:

b. Potential control not exercised:

I broke the vase on purpose

c. No control:

I carelessly broke the vase

I was pushed down to the concrete and broke the vase

It is extremely important to point out that, in the concept of control, the passives indicate that there is no control in the part of the subject NP, whether it is a human NP or a non-human NP. We now see the two semantic functions of the passive construction: impersonalization and non-control.

On the other hand, the causatives indicate that there is potential for the causee's retention of control when the causee is an animate. According to Comrie, however, when the causee is an inanimate entity such as a tree or a pen, which has no potential for exercising any control over the situation, the question of control

\footnotetext{
${ }^{3}$ For the elaborate analyses of the semantics of the suffixes -rare and -sase, see Tokunaga (1991).
} 
does not arise. The point to be made here is that one of the semantic functions of causatives is a clear indication of the causee, namely, the agent as the subject NP. Another function is the causee's retention of "control". The idiomatic expressions exemplified in (12) further illustrate the semantic natures of naru 'become' and of suru 'do' in terms of "control".

$\begin{array}{cccccc}\text { a. } & \text { (Watashi } & \text { wa) } & \text { Tanaka-san ni o sewa-ni } & \text { nar-imashita } \\ \text { I } & \text { Top. } & \text { Mr. Agnt was } & \text { taken care of }\end{array}$

"(I) was taken care of by Mr. Tanaka"

b. (Watashi wa) Tanaka-san o o sewa shi-mashita

"(I) took care of Mr. Tanaka"

Naru 'become' in (12a) does not indicate that the action of 'taking care of someone' was done under the control of the agent, namely, Mr. Tanaka in the oblique position. It does not also indicate that the action is done by the speaker's wish. In other words, naru does not indicate "control" of anyone. On the other hand, suru 'do' (12b) clearly indicates that the action of 'taking care of someone' was done by the agent, namely, the speaker NP as the subject. (12) shows that suru denotes one's control while naru does not.

The suffixes -sase and -rare also show such dychotomy in terms of 'control': the causative suffix indicates only semantic function of causative, which always denotes the agent's force or control, while the suffix -rare shares four grammatical functions such as 'spontaneity', 'potential'. 'formation of respectful form', and 'passive'. All the four functions are semantically "out of an agent's control": 'spontaneity' denotes that an event happens by itself as observed in (13a), that is, it does not implicate even an existence of an agent. The Japanese notion of 'potential', one's ability, also seems to be considered something which exists without one's control or consciousness as in (13b). I already discussed the use of -rare for the form of respect and the passives and their 'non-controlness'.

a. Soyokaze ga hada ni kimochi yoku kanz-erare-ta (Araki 1980: 15) breeze Nom skin feeling well feel-Spont-past

"The breeze felt nice to my skin"

$\begin{array}{llllll}\text { b. } & \begin{array}{l}\text { Ashita } \\ \text { tomorrow }\end{array} & \text { wa tabun ko-rare-ru } & \text { to } & \text { omo- } & \text { imasu } \\ & \text { Toprobably come-Pot.-pres } & \text { Qt. } & \text { think- } & \text { polite }\end{array}$

ga, ko-rare-nai toki wa o-denwa itashimashoo (Araki p.28)

but come-Pot.-not when phone will do

"I think I can come tomorrow, but I'll call you if I can't" 
The term "spontaneity" is used in the traditional Japanese grammar. Its function overlaps with that of "passives". Thus, the passive form is often used in the English translation as in (13a). However, in Japanese, while the passives imply an agent, "spontaneity" does not: there is a definite difference in meaning between sentences such as "the book was stolen" and "it can be thought that someone stole the book" although both contain passive constructions. The former implies that there is an agent, namely, a thief and the latter does not. The difference in interpretations between the passives and spontaneity is that the former implicates an agent and the latter does not. However, both indicate that there is no control in the part of the referent of the subject when the VP is marked by -rare or contains -naru in Japanese.

In short, naru 'become' and the suffix -rare indicate "no control" in the part of the subject. On the other hand, suru 'do' and the suffix -sase indicate "control" in the part of the subject.

Chart \#1 illustrates the difference between the semantic functions of passives and causatives, and between the inchoative verb naru 'become' and the active verb suru 'do' in terms of control:

\begin{tabular}{||c|c|c|c|c||}
\hline & \multicolumn{2}{|c|}{ Passive vs. Causative } & \multicolumn{2}{c|}{ Naru vs. Suru } \\
\hline Subject NP & recipient & agent & $\begin{array}{l}\text { experien- } \\
\text { cer }\end{array}$ & agent \\
\hline Control & -- & + & -- & + \\
\hline
\end{tabular}

\section{Chart \#1}

Chart \#1 clearly shows the semantic dichotomy between the suffixes and the verbs in terms of "control". Naturally a question arises as to why the linguistic items with non-control are to be used to indicate politeness for superiors as the respectful form and those with control for the speaker himself or insider as the humble form in Japanese.

The answer seems to be that a basic human desire is to treat the respect for dignity as a social norm or value as Brown \& Levinson argue. In Japanese, the use of honorifics does seem to satisfy this basic human desire that Brown and Levinson argue $^{4}$. However, it seems to be more the case in Japanese that, through using honorifics, one probably indicates his acknowledgement of the difference between himself (insider) and the person to whom he shows his respect (outsider).

The answer to the question why Japanese use the forms of no-control to indicate one's respect for outsiders and the forms of control in describing one's

\footnotetext{
${ }^{4}$ For argument against their claim, see Matsumoto (1988).
} 
action to indicate his humbleness or politeness for outsiders can be found in searching the Japanese concept of respect.

\subsection{The notion of respect in Japanese}

An anthropologist and ethnolinguist, Araki (1980) and a linguist, Ikegami (1981) have independently claimed that the passive suffix -rare and the inchoative verb naru 'become' indicate that an incident happens by itself from an unknown source. Both scholars also claim that this indication is the conceptual attitude that Japanese possess for a respectable existence, whether the respectable existence is human or non-human. They argue that the use of these semantically impersonal items for the respectful form reflects the Japanese value of a natural occurrence rather than human force. Sentence (14) is a classical expression for the situation when the Lord is appearing in front of people.

$$
\begin{array}{ll}
\text { Otono- } & \text { sama no o-nari (Ikegami's (138), p.252; Araki p.39) } \\
\text { Lord }
\end{array}
$$

"Lord has arrived (appeared)"

Ikegami explains that naru in (14) indicates that the Lord was non-existent and now has appeared by a superhuman power. In other words, a matter described with naru is perceived as what is beyond one's "control". Araki also explains that an honorable person like the Lord would never come by his own will, but appears by a power beyond human control.

Similarly, Hashimoto (1969), Makino (1974) and Araki argue that the passive suffix -rare is derived from the notion of jihatu, "spontaneity", which refers to facts which occur beyond human control, such as the creation of mountains, or the change of the state of water to steam when it is boiled. Araki claims that a respectable entity for Japanese must be things that exist beyond one's control, force, or power.

It seems that the choice of the inchoative verb naru and the passive suffix rare for the form of respect is consistent with a universal notion of politeness, although in Japanese the philosophical concept for the notion of respect seems to be directed toward a superhuman power. Under this Japanese concept of respect, the use of the linguistic means which indicate "non-control" and an existence by a power beyond humans makes logical sense.

I have demonstrated that there is a structural dichotomy in the expressions of the Japanese honorifics, that is, the expressions with the linguistic items which indicate "non-control" and those with the linguistic items which indicate "control". The active verb suru 'do' and the causative suffix -sase indicate "control" of the agent. The inchoative verb naru 'become' and the suffix -rare indicate "non-control". While the former is used for the humble form, which refers to the speaker himself or an insider, the latter is used for the form of respect, which refers to an outsider. This linguistic dichotomy observed in the structure of Japanese honorifics probably indicates the conceptual attitude that Japanese possess for the speaker himself and some respectable person; perception of a respectable person's action or matter as something beyond human control. Respect must be expressed with feelings of 
awesome as if it belongs to something supernatural. On the other hand, the linguistic indication of the agent for the humble form seems to indicate that the Japanese perceives something controllable as what belongs to himself. This concept may also be related to the notion of "insiders" and "outsiders". The linguistic dichotomy in the honorific system is an indication that the Japanese pragmatic rule is a keen realization of the distinction between the speaker himself/insiders and nonspeakers/outsiders. In fact, this type of linguistic dichotomy, which seems to be derived from this distinction of "insiders" and "outsiders", is observed in other linguistic items in Japanese. In the following, some of the linguistic manifestations of the concept of "insider" and "outsider" will be exemplified for the further support to my claim that the concept of the distinction between "insider" and "outsider" is engraved in the linguistic system of the Japanese language.

\section{Insiders vs. Outsiders manifested in the Japanese language}

There exists the strict sense of the distinction between the speaker himself (including his "insiders") and non-speaker/non-insiders (i.e. "outsiders"). This distinction is so strong that the notion is engraved in the system of the language. An appropriate choice in the pragmatics of Japanese cannot be made without deep understanding of this notion.

The learners of Japanese often have trouble making a correct choice and grasping the appropriate usage in terms of lexical items and structures, such as choice between two giving verbs, choice between active and passive constructions, and usage of verbs and of compound VPs. I shall briefly discuss the linguistic manifestation of the notion of "insiders" and "outsiders", examining three examples.

\subsection{Choice between Ageru 'give' and Kureru 'give'}

The choice between the giving verbs can appropriately be made only by understanding the speaker's relation with the giver and with the receiver. If the speaker considers the giver his "insider", whether the giver is his family member or emotionally close person, he must choose ageru 'give' to describe the giver's action as in (15). If he considers the receiver his "insider" and he wants to describe that the giver initiated the giving action, he must choose kureru 'give', placing the receiver $\mathrm{NP}$ in the indirect position as in (16).

(15) Giver: Tom, Speaker's brother

Receiver: Mary, Speaker's friend

a. Tom wa Mary ni hana o ageta

flower give

"Tom gave the flowers to Mary"

b. *Tom wa Mary ni hana o kureta 
Giver: $\quad$ Mary, Speaker's friend

Receiver: Tom, Speaker's brother

a. Mary wa Tom ni hon o kureta

book

"Mary gave the book to Tom"

b. *Mary wa Tom ni hon o ageta

In Kuno's empathy framework, it is explained that "empathy", the speaker's identification with a participant, is with Tom, the speaker's brother, in (15) and (16). The speaker's relation with Tom is considered closer than that with Mary in the Japanese society, because Tom is his family member.

Diagram \#1 illustrates the shift of the speaker's "empathy" in his relation to the giver and the receiver.

\section{Diagram \#1}

Speaker > X (X can be: speaker's family member close friend acquaintance any third person)

$\begin{aligned} \mathrm{X}> & \mathrm{Y} \mathrm{(for} \mathrm{example:} & \\ & \mathrm{X} \text { (family member) } & >\mathrm{Y} \text { (close friend) } \\ & \mathrm{X} \text { (closer friend) } & >\mathrm{Y} \text { (friend) } \\ & \mathrm{X} \text { (friend) } & >\mathrm{Y} \text { (acquaintance) } \\ & \mathrm{X} \text { (acquaintance) } & >\mathrm{Y} \text { (stranger), etc.) }\end{aligned}$

As seen in the example of the giving verbs, appropriate usage of Japanese is not possible without understanding this strict sense of the distinction between "insiders" and "outsiders".

\subsection{Choice between Active and Passive constructions}

Another example which requires the realization of the notion of "insiders" and "outsiders" is observed in the choice of passive constructions. In describing a situation where "Jim saw Nancy's room", the speaker would be able to choose either the active or the passive construction. The active construction such as (17a) delivers a neutral description, while the passive construction such as (17b) tells much more information about the speaker's relation with Nancy and also his feeling.

$\begin{array}{llll}\text { a. Jim wa Nancy no heya o } & \text { mi-ta } \\ \text { of } & \text { room Acc. } & \text { see-past }\end{array}$

"Jim saw Nancy's room" 
b. Nancy wa Jim ni heya o mi-rare-ta

English translation of (17b) is not possible because of the pragmatic implication of the Japanese passives with certain verbs. As Araki $(1980,1983)$ suggests, the concept of "passive" seems to be derived from the Japanese philosophical concept of "out-of-controlness". It has been said that the implication that the Japanese passive construction indicates is "adversity". Thus, (17b) could be interpreted that Nancy did not like the fact that Jim saw her room because of the use of the passive construction. However, the passives do not always produce adversive connotation, as seen in (18).

$\begin{array}{lll}\text { a. Nancy wa } & \begin{array}{l}\text { sensei } \\ \text { teacher }\end{array} & \begin{array}{l}\text { ni homer-are-ta } \\ \text { Agnt. praise-Pass.-past }\end{array}\end{array}$

"Nancy was praised by the teacher"

b. Haha ni hana o age-te, totemo yorokob-are-ta mother Dat. flowers Acc. give-Ger. very please-Pass.-past

"(I) gave the flowers to my mother, and she was very happy."

(Lit.)...., and I was pleased by my mother

If Nancy in (18a) is the speaker's child, it certainly indicates the speaker's happiness. Example (18a) can also be a neutral description, because "being praised" is not a controllable situation for Nancy or the speaker. The use of the passive is a natural choice to describe the situation. It does not indicate any adversity, because of the semantic nature of the verb "praise", which indicates positive connotations. Example (18b) also never indicates negative connotations, for the same reason as for (18a). These examples indicate that the semantic nature of the Japanese passives is not "adversity", but rather, in my analysis, that "the conceptual direction of an action is uncontrollably directed toward the speaker or/and the recipient". Thus, these could be an interpretation of "adversity" when the semantic nature of the verbs can be interpreted as adversity under particular situations. The passives imply that the direction of an action toward the speaker and/or the recipient indicates that the speaker considers the recipient his "insider". Thus, the passive construction cannot be used unless the speaker feels closer to the person affected by the agent's action, when there is a choice for the active construction.

The notion of clear distinction between "insiders" and "outsiders" is also engraved in the semantic property of the Japanese verbs. The inherent directionality of the verbs is either deictic or totally unconcerned with the speaker.

\subsection{Choice of verbs}

The third example, which indicates that the appropriate utterances can be made by the understanding of the notion of "insiders" and "outsiders", is observed in choice of verbs for the speaker himself and those for others. The students of Japanese often have a great deal of trouble expressing situation, in which they are 
directly involved, due to the lack of understanding the inherent directionality of the Japanese verbs. The inherent directionality that the Japanese verbs indicates is toward or away from with respect to either the subject NP or the speaker NP. In Japanese, situations like (19) cannot be expressed with only the main verbs such as call, invite and buy, since the speaker or an insider is directly involved in the situations for (19).
a. Tom called me yesterday
b. Tom invited me to a party
c. Tom bought the clock from me

The counter-expressions in Japanese for (19) are observed in (20)-(22).

\begin{tabular}{|c|c|c|c|c|c|c|}
\hline \multirow[t]{2}{*}{ (20) } & $\begin{array}{l}\text { Tom } \\
\text { Tom }\end{array}$ & $\begin{array}{l}\text { wa } \\
\text { Top. }\end{array}$ & $\begin{array}{l}\text { kinoo } \\
\text { yesterday }\end{array}$ & $\begin{array}{l}\text { (watasi } \\
\text { I }\end{array}$ & $\begin{array}{l}\text { ni) } \\
\text { Dat. }\end{array}$ & \multirow[t]{2}{*}{$\begin{array}{l}\text { denwa } \\
\text { telephone }\end{array}$} \\
\hline & $\begin{array}{l}\text { shite- } \\
\text { do }\end{array}$ & $\begin{array}{l}\text { (a) } \\
\text { (b) }\end{array}$ & $\begin{array}{l}\text { kureta } \\
\text { gave } \\
\text { kita } \\
\text { came }\end{array}$ & $\begin{array}{l}\text { yo } \\
\text { emph. } \\
\text { yo }\end{array}$ & & \\
\hline
\end{tabular}

(a) "Tom called me yesterday (and I am happy about it)"

(b) "Tom called me yesterday (although I had not expected that)"

(21) Tom wa (watasi o) paatii ni yonde-kureta yo

Acc. party Dat. invite-gave emph.

"Tom invited me to a party (and I am happy about it)"

$\begin{array}{llllll}\text { Tom wa (watasi } & \text { kari) } & \text { sono tokei o } & \text { katte- (a) } & \text { itta yo } \\ \text { from that clock Acc. buy } & \text { went } \\ & & & & & \text { (b) } \begin{array}{l}\text { kureta yo } \\ \text { gave }\end{array}\end{array}$

(a) "Tom bought the clock from me (and left me with it)"

(b) "Tom bought the clock from me (and I am grateful for that)"

All the VPs in (20)-(22) contain one of the supporting verbs, kureru 'give', kuru 'come', and $i k u$ 'go', which indicate the speaker's deictic position. In my analysis, the inherent directionality that the verbs other than the deictic verbs (e.g., kureru, kuru and $i k u$ ) indicate is either toward or from the subject NP, regardless of Person. Thus, the speaker NP can appear only as the subject of the sentences. When the speaker NP is placed in an oblique position, the sentence requires one of the deictic verbs as a supporting verb. In this way, the deictic verb indicates that the action denoted by the main verb is directed with respect to the speaker. This obligatory use of a deictic verb is also applied when the insider NP is in an oblique position.

For example, if Tom called Mary instead of the speaker, the speaker can simply say Tom wa mary ni denwa o shita yo "Tom called Mary" as a description of the fact when the speaker's relation to Tom and Mary is equal. However, if Mary 
is an insider and the speaker wants to express his happiness for Mary's receiving Tom's phone call, he would use the supporting verb kureru. If he was annoyed by Tom's phone call to Mary, he may use the other supporting verb kuru 'come' to indicate that Tom's action was done beyond Mary's or the speaker's control. Thus, the hearer will know that Mary is an in-group member to the speaker either physically as his sister or psychologically as his close friend (See Tokunaga 1986 for more discussion).

\section{Conclusion}

I have discussed that the notion of "insiders" and "outsiders" is engraved in the structure of the Japanese language. This notion also seems to be reflected in the structure of the Japanese honorifics: the use of the inchoative verb naru 'become' and the passive suffix -rare for the respectful form indicates that the speaker considers a person superior/respectable to himself as an "outsider", namely, someone who is beyond his reach, whereas the use of the active verb suru 'do' and the causative suffix -sase for the humble form indicates that the speaker perceives himself and an "insider" as the very real entity. This study shows that the dichotomy of the structure of the honorifics is one linguistic manifestation of the notion of "insiders" and "outsiders" in Japanese.

\section{References}

Araki, H. (1983) Nihongo kara Nihonjin o kangaeru (A study of the Japanese people from the viewpoint of their language). Tokyo: Asahi-Shinbun-Sha.

Araki, H. (1983) Keigo Nihonjin Ron (Honorifics: the Japanese). Kyoto: PHP Kenkyuu-jo.

Doi, T. (1973) The anatomy of dependence. Tokyo: Kodansha International, Ltd.

Ikegami, Y. (1981) "Suru" to "Naru" no Gengo-gaku: Gengo to Bunka no Taipologii e no shiron. (Linguistics of "Do" and "Become": A tentative typological analysis of language and culture). Tokyo: Taishuukan.

Ikegami, Y. (1982) "Hyoogen Koozoo no Hikaku: Suruteki na gengo to Naruteki na gengo" (A comparison in the mechanism of expression: Do-language and Become-language). In Kunihiro (ed.) Nichi-Ei-Go Hikaku Kooza Vol.4: Hassoo to Hyoogen (Comparative studies of Japanese and English Vol.4: Conception and expression). Tokyo: Taishuukan, pp.67-109.

Kuno, S. (1978) Danwa no Bumpoo (Grammar of discourse). Tokyo: Taishuukan.

Kuno, S. (1987) Functional syntax: Anaphora, discourse and emphathy. Chicago: The University of Chicago Press.

Matsumoto, Y. "Reexamination of the universality of face: Politeness phenomena in Japanese". Journal of Pragmatics 12: 403-426. North-Holland.

Tokunaga, M. (1985) "A strategy for objective expressions in Japanese". In Journal of Asian Culture Vol.9: 181-198. Graduate Studies in Asian Studies at UCLA. 
Tokunaga, M. (1986) "Affective deixis in Japanese: A case study of directional verbs". Ph.D. dissertation. The University of Michigan.

Tokunaga, M. (1988) "A paradox in Japanese pragmatics". Papers in Pragmatics 2(1/2): 84-105. Antwerp: International Pragmatics Association.

Tokunaga, M. (1988) "Integrating pragmatics into the language instruction: A rule for choice of appropriate expressions in Japanese". (unpublished paper). Presented at the Conference on Innovations in Teaching Chinese and Japanese at Rutgers University, March.

Tokunaga, M. (1989) "A paradoxical functions of passives in Japanese pragmatics". To appear in Papers of the LACUS Forum. Linguistics Associations of Canada and the United States.

Tokunaga, M. (1990) "Structural dichotomy and pragmatics in Japanese". Paper presented at the Conference on Japanese Linguistics and Language. Middlebury College.

Tokunaga, M. (1991a) "Integrating pragmatics and pedagogy: A case of the Japanese passives and causatives". Gengo Kyooku Kenkyu Vol.2: 105-114. Institute of Linguistics and Language. Kanda University of International Studies.

Tokunaga, M. (1991b) "Semantics of the passive and causative suffixes in Japanese". Pan-Asiatic linguistics: Proceedings of the Third International Symposium on Language and Linguistics Vol.I: 324338. Chulalongkorn University. 